\title{
DESIGNS FOR ENVIRONMENTAL DISCOURSE REVISITED: A GREENER ADMINISTRATIVE STATE?
}

\author{
John S. Dryzek \\ Social and Political Theory Program \\ Research School of Social Sciences \\ Australian National University \\ Canberra, ACT 0200 \\ Australia \\ jdryzek@coombs.anu.edu.au
}

Prepared for Robert Paehlke and Douglas Torgerson, eds, Managing Leviathan: Environmental Politics and the Administrative State, $2^{\text {nd }}$ edition 
The administrative state is not what it used to be, in environmental affairs no less than elsewhere. There is still plenty of administration around, even if we think of it in classic Weberian terms: hierarchical and pyramid shaped, with a clear division of labor between subunits in the hierarchy. However, many governments have been affected by reform waves as well as the press of structural forces that complicate the picture by introducing other forms of collective choice into administration. One popular set of reforms at least in the AngloAmerican liberal democracies is the marketization inspired by market liberalism and its associated public choice theory. Here the idea is to make government more like the market, not just through privatization of service delivery, but also through the introduction of competition within government structures (such as internal markets) and the establishment of consumer sovereignty in the operation of government. Paradoxically, such reform also requires a stronger state center to coerce the system into being more like a market. ${ }^{1}$ Another set of reforms occurs with the "new governance" that shares some of the decentralist ideology of market liberalism on service delivery, but also sees government in forms of networks of partnership transcending traditional private-public boundaries, involving voluntary associations and corporations as well as government departments. Structurally, the rise of "transgovernmentalism" means that problem-solving cuts across traditional boundaries, including national boundaries. ${ }^{2}$ A more powerful structural force emanates from the transnational political economy - though, paradoxically, this may actually function so as to consolidate the hold of the administrative center, because of the demands it makes for states to abide by the dictates of international competitiveness. The ideology of economic globalization reinforces this structural force, as governments everywhere come to believe they must sustain investor confidence and open their markets.

The administrative state has also come in for an intellectual battering from green political theory, an enterprise that blossomed in the 1990s. The majority view among green theorists is now clearly democratic. Moreover, the democracy in question is not a mere representative one that takes on green parties and green programs, otherwise engaging in business as usual (but see Goodin's rearguard action on behalf of a more conventional green politics $\left.{ }^{3}\right)$. Though the details vary, proposals for green democracy generally involve more participatory and discursive invigoration in the context of decision making that is not simply left to the relevant department of government. ${ }^{4}$ While this theoretical program has had nothing like the impact of market liberalism and public choice, it does resonate with a range of real-world deliberative and democratic reforms that have been adopted, generally without much input from theorists. Paehlke pointed out in 1988 that the environmental area has led all others in democratic reforms such as right-to-know legislation, public inquiries, impact assessment with mandatory public comment, and the like. ${ }^{5}$ This momentum continued in the 1990 s, with various sorts of policy dialogues, citizens juries, planning cells, consensus conferences, deliberative opinion polls, and community-organized popular epidemiology joining more established practices such as mediation and regulatory negotiation. These reforms and exercises often reached into the territory once described as administration. Habermas sketches a "two track" deliberative democracy with deliberation occurring in the public sphere and more formally in the legislature. ${ }^{6}$ But the intertwining of deliberation and

\footnotetext{
${ }^{1}$ Andrew Gamble, The Free Economy and the Strong State (Basingstoke, Macmillan, 1988).

2 Anne-Marie Slaughter, “The Real New World Order," Foreign Affairs, 76 (1997).

${ }^{3}$ Robert E. Goodin, Green Political Theory. Cambridge: Polity Press, 1992.

${ }^{4}$ See, most recently, Graham Smith, Deliberative Democracy and the Environment (London: Routledge, 2003).

${ }^{5}$ Robert Paehlke, "Democracy, Bureaucracy, and Environmentalism," Environmental Ethics, 10 (1988), pp. 291-308.

${ }^{6}$ Jürgen Habermas, Between Facts and Norms: Contributions to a Discourse Theory of Law and Democracy (Cambridge, MA: MIT Press, 1996).
} 
administration suggests a "three track" model, with administration itself a deliberative democratic site.

This chapter does not however constitute a celebration of the encroachment of deliberative democracy onto the territory of the administrative state. For this encounter does not necessarily produce happy outcomes. Seemingly democratic exercises might provide legitimating cover for business as usual - especially problematic when that business is itself being pulled in a particular anti-democratic direction by market liberalism and associated structural economic forces. Co-optation and deradicalization of environmentalist and citizen participants in these exercises is also possible. Overall, these sorts of developments might contribute to reduction in vitality of the green public sphere, whose importance has been established by Torgerson. ${ }^{7}$ What needs to be done, then, is to sort out the most productive kind of relationship between the administrative state and deliberative democracy. There may turn out to be synergies, but there may also be irreducible conflict. We might even think about the displacement of the administrative state by discursive democracy. And we should also be alive to the possibility that discursive democracy in the public sphere can actually benefit from a relatively obtuse administrative state, one that does not open itself up along the lines I have sketched.

In this chapter I will try to navigate a path through these thickets. I will begin by setting out the administrative state and a discursive democratic alternative in ideal-type terms, and examine their strengths and weaknesses in a way that is comparative but static. This comparison will come down in favor of discursive democracy as being intrinsically more likely to promote ecological values. However, diagnosis of the faults of the administrative state can be instructive, not just by pointing to the qualities that any institutional alternatives should seek, but also in identifying traps into which these alternatives might themselves fall. I then move to a more nuanced and analysis of the relationship between the administrative state and democracy, showing that green democratization of the administrative state is a worthwhile project - but exactly how and when it can take place depends crucially on the political-economic context.

\section{The Case Against Administration as Such}

The fact that the Western world's environment is today somewhat safer, cleaner, and more securely protected than it was thirty years ago owes much to the efforts of the administrative state. But despite any such accomplishments, the effects of the administrative state in environmental affairs today seem problematical. What, then, is wrong with the administrative state when it comes to environmental protection? At least three shortcomings may be identified. First, in terms of the basic criterion of environmental quality, administration is less than it once was. That is, despite any past achievements, the administrative state is running out of steam. While the early years of administrative regulation may be credited with some fairly obvious improvements in environmental quality, further achievements are hard to come by. A comprehensive survey of the evidence on this score is beyond the scope of this chapter-and in any case, many of the sources that one might cite are highly partisan, producing conflicting evidence. This much, it seems, is apparent: in the United States and elsewhere, the early years of environmental concern around 1970 led to the adoption and implementation of policies with clear and obvious positive effects on environmental quality. Come the 1980s, the question of whether further policy efforts do or would produce benefits sufficient to justify their costs (irrespective of the metrics one applies) became controversial. Later, new approaches to environmental improvement involving integration of economic and environmental concerns were pioneered,

\footnotetext{
${ }^{7}$ Douglas Torgerson, The Promise of Green Politics: Environmentalism and the Public Sphere (Durham, NC: Duke University Press, 1999).
} 
especially in Northern European countries. But these approaches did not involve management of the economy-environment interface by administrative agencies. Instead, they saw a politics that engaged industry, government, and (moderate) environmentalists in complex relationships, sometimes adversarial, sometimes cooperative.

Administration in the environmental arena thus confronted a problem also found in other areas of administration: diminishing marginal returns to effort. For example, the Soviet experience shows that central economic planning is an excellent device for rapid transformation of a static agrarian society into an industrial power-but thoroughly inept after that initial transition has been secured. In education, it is fairly easy for an administrative state quickly to convert an illiterate population to a literate one - but very hard thereafter to equalize educational opportunity, eradicate pockets of illiteracy, or otherwise promote educational achievement. Turning to social welfare, it is easy to virtually eliminate malnutrition, or provide a decent standard of public health — but hard to maintain and refine a system of welfare and health care that does not produce perverse and conflicting incentives, or generate attitudes of helplessness and dependency in clients. In short, as Charles Lindblom puts it, administrative systems have "strong thumbs, no fingers." 8

A second shortcoming is that any achievements which can be credited to the administrative state may have been purchased at the cost of advancing bureaucratization and the instrumental rationalization or control of society more generally. This is Max Weber's scenario: zweckrationalitat triumphs precisely because it copes well with complex problems, but attendant upon this triumph is the demise of the more congenial features of human existence and association. Weber's fears are today echoed by everyone from conservative free marketeers to critical theorists and feminists. ${ }^{9}$

A third set of issues stems from the fact that the state as a whole has priorities which have little to do with environmental quality, which may be overridden when it clashes with these other priorities. The precise content of state priorities is a matter of some dispute. But at a minimum, all states face the need to establish domestic order, secure themselves in a potentially hostile international order, and raise the finance for these activities. ${ }^{10}$ Democratic states in particular are also faced with the need to legitimate the political economy in the eyes of their citizens most likely to suffer from the inequality and instability that the capitalist political economy can produce. The main legitimating device is the welfare state. Finally, both finance and legitimacy point to the continuing need states have to maintain business confidence in their activities, for otherwise they will be punished by economic downturn. While inexpensive environmental programs producing clear and substantial benefits will have little impact here, environmental policy may be a candidate for such punishment if and when diminishing returns of the sort discussed earlier set in. However, this scenario assumes a conflict between environmental values and economic goals. As we will see, discourses of sustainable development and ecological modernization seek to dissolve this conflict.

The roots of these three defects of the administrative state lie in its epistemology and in its context. The epistemology of administration - its implicit theory of knowledge - is an instrumental-analytic one. That is, administration implicitly regards rationality as the capacity to devise, select, and effect good means to clarified and consistent ends. In the context of complex problems, this capacity also requires breaking such problems down into

\footnotetext{
${ }^{8}$ Charles E. Lindblom, Politics and Markets: The World's Political--Economic Systems (New York: Basic Books, 1977).

${ }^{9}$ For a free marketeer critique along these lines, see Milton Friedman and Rose Friedman, Free to Choose (New York: Harcourt Brace Jovanovich, 1979); for a critical theorist's account, see Ralph Hummel, The Bureaucratic Experience (New York: St. Martin's, 3rd ed., 1985); for a feminist angle, see Kathy E. Ferguson, The Feminist Case Against Bureaucracy (Philadelphia: Temple University Press, 1984).

${ }^{10}$ See Theda Skocpol, States and Social Revolutions (New York: Cambridge University Press, 1979), pp. 24 33.
} 
simpler components. As Weber pointed out long ago, bureaucracy is a device for the task decomposition and allocation which is necessary whenever problems overwhelm the information processing capabilities of a single individual (or small group of individuals). For all their protestations about matrix organization (which has been espoused, for example, by the United States Environmental Protection Agency), task forces, organic structures, mosaics, and the like, and despite the best efforts of organization theorists over the years, most large organizations are still Weberian - that is, hierarchical and pyramid-shaped. Both authority and - implicitly_-knowledge are centralized at the apex of the pyramid. The apex is assumed to know better than the lower levels, at least to the extent it is assigning and coordinating tasks among them, thereby ensuring that overall solutions to problems will be constructed in harmonious and effective fashion. Market-oriented reforms inspired by public choice theory often reinforce this model, even as they are justified in opposition to it. Such reforms generally involve a strengthened coordinating role for the administrative center, which organizes and oversees contract and competition in service delivery.

Now, Weber himself regarded this instrumental-analytic epistemology as an effective one, at least in terms of a capacity to resolve complex problems, if not in terms of the unfortunate byproduct of a loss of meaning in human existence. But it is now abundantly clear that there are limits to the capacity of bureaucratic forms of organization - and to the instrumental-analytic notion of rationality undergirding them-when it comes to truly complex problems. The reason is this: effective problem decomposition must be intelligent rather than arbitrary. And intelligent decomposition in turn requires that the sets and subsets into which a complex problem is divided should be relatively autonomous - that is, with a minimum of interactions across their boundaries. As complexity grows, then so will the number and variety of such interactions, until at some point the analytical intelligence at the center of the decision system is overwhelmed. The result is that time produces not a convergence on less problematical conditions, but endless displacement across the boundaries of sets and subsets. ${ }^{11}$

To what extent does this kind of administrative incapacity apply to environmental affairs? Ecological systems are indeed highly complex; as Barry Commoner puts it in crude but effective fashion, the first law of ecology is that "everything is connected to everything else." $" 12$ One consequence is that attempts to resolve one environmental problem (for example, by building tall smokestacks to reduce local pollution) often simply create or exacerbate another kind of problem (for example, long-distance pollution such as acid rain). ${ }^{13}$ The fact that most environmental agencies operate under the authority of a series of single-medium statutes (for example, the U.S. Clean Air Act, Clean Water Act, and Resource Conservation and Recovery Act) further exacerbates this situation, given that none of these statutes recognizes the possibility of cross-medium displacement.

The context of environmental administration can be as debilitating as its epistemology. As I have already noted, states in market systems are constrained by their need to maintain the confidence of potential investors. Any state actions that threaten the profitability of industry and commerce are automatically punished by reduced investment

\footnotetext{
${ }^{11}$ For details on this general argument, see Christopher Alexander, "A City is not a Tree," Architectural Forum 122:1 and 122:2 (1965), pp. 58-61 and 58-62; Todd R. La Porte, ed., Organized Social Complexity: Challenge to Politics and Policy (Princeton: Princeton University Press, 1975); John S. Dryzek, "Complexity and Rationality in Public Life," Political Studies 35 (1987), pp. 424-442.

${ }_{12}$ Barry Commoner, The Closing Circle (New York: Bantam Books, 1972), p. 29.

${ }^{13}$ For details on this argument as applied to ecological problems, see John S. Dryzek, Rational Ecology: Environment and Political Economy (New York: Basil Blackwell, 1987), pp. 16-20.
} 
followed by economic downturn. ${ }^{14}$ If indeed there are diminishing returns to state effort on the environment, then it becomes increasingly likely that potentially effective environmental policies will be vetoed by the anticipation of market punishment. This perhaps explains the inaction on climate change of all governments, including those nominally committed to the cutbacks on greenhouse gas emissions specified in the 1997 Kyoto Protocol. Any significant amelioration of the problem will require action that is very costly not just to energy-using industry and consumers, but also to national economies. The potential economic impact may explain why real action on this issue has been very slow in coming. Paradoxically, apologists for polluting industry of all sorts are well aware of the high financial and economic costs associated with limitation of greenhouse gas emissions, which is why they have an interest in keeping this issue on the political agenda. Attention may be deflected from other environmental issues where the cost-benefit ratio may be less favorable to inaction.

There are, then, a number of automatic constraints upon any state that operates in a market economy. These constraints apply irrespective of the degree to which the state features democratic as opposed to administrative control. However, the presence of these constraints can increases the relative weight of administration, because executive government is less subject to the indeterminacy in the production of public policies that democracy connotes. ${ }^{15}$

When the competitive market and its constraints are weakened in oligarchic or monopoly capitalist economies, some less automatic, but no less effective, constraints upon the administrative state come into play. Corporations in such circumstances become very powerful political players. Their influence can be exercised directly upon administrative agencies, as well as in legislative politics. Thus agencies purposely insulated from legislative oversight (in the U.S., the "New Deal" type, such as the Securities and Exchange Commission, or Nuclear Regulatory Commission) prove vulnerable to capture by the very interests they are supposed to regulate or control. To prevent this kind of capture, the US Environmental Protection Agency was established under the "action-forcing" authority of Congress. ${ }^{16}$ But the events of the early 1980s, when President Reagan handed the EPA to individuals hostile to the very idea of environmental regulation, demonstrated that this kind of deliberately politicized agency too can be deflected from its mission by determined businesses conspiring with zealots in the upper reaches of the executive branch. And despite some undeniable achievements, the earlier history of the EPA shows that politicization of an agency can lead to strange bedfellows and peculiar compromises. Along these lines, Bruce Ackerman and William Hassler chronicle the life and times of a coalition between Western environmentalists and Eastern coal producers which pressed for a policy of forced scrubbing for emissions from all coal-fired power stations. ${ }^{17}$ This policy effectively discriminated against Western producers of relatively clean, low-sulphur coal, thus keeping the West pristine and the East polluted.

This last example shows that environmental interests are not without influence in the administrative state, especially, perhaps, when they can ally with non-environmentalists, such as the Eastern coal producers just mentioned, or fiscal conservatives opposed to government subsidy of nuclear power. But when all is said and done the struggle is not an equal one.

\footnotetext{
${ }^{14}$ See Fred Block, "The Ruling Class Does Not Rule: Notes on the Marxist Theory of the State," Socialist Revolution 7:3 (1977), pp. 6-28; Charles E. Lindblom, “The Market as Prison,” Journal of Politics 44 (1982), pp. 324-336.

${ }^{15}$ See John S. Dryzek, Democracy in Capitalist Times: Ideals, Limits, and Struggles (Oxford: Oxford University Press, 1996), p. 80.

${ }^{16}$ See Bruce A. Ackerman and William T. Hassler, Clean Coal/Dirty Air (New Haven: Yale University Press, 1981), pp. 7-12.

${ }^{17}$ Ibid.
} 
Business starts from a "privileged" position in interest group policies. ${ }^{18}$ Business has more (financially) at stake; it has more to spend on lobbying, litigation, and campaign contributions; and it has more with which to threaten administrators and politicians (including withdrawal of the cooperation necessary to implement many public policies).

\section{Institutional Alternatives: Discursive Designs}

An agenda for institutional change can be constructed by starting with the epistemological shortcomings of the administrative state. In direct contrast to the Weberian argument, let me suggest that institutions can be expected to resolve complex problems to the extent they embody principles of free discourse among equals. Institutions of this sort will have the added advantage of undermining the instrumental rationalization and domination attendant upon administration and the like. Later I shall suggest that such discursive institutions are themselves prone to subversion by some of the more insidious aspects of the very same context which constrains the existing efforts of the administrative state, but for the moment a focus on the positive is in order.

The principles of free discourse I have in mind are those elaborated by critical theorists and others who have attended closely to the linguistic aspect of political life. One of the more well-known of such statements is associated with Jürgen Habermas's exposition of the idea of communicative rationality. ${ }^{19}$ To Habermas, an interaction is communicatively rational to the extent that it proceeds among equally competent individuals under conditions free from domination, deception, self-deception, and strategizing. All that remains is the "forceless force of the better argument," which can relate to both normative judgments and empirical conditions and relationships. Habermas himself treats the details of social problem solving as the domain of "administrative power". It is subject to the deliberative democracy of the legislature (and, at one remove, the public sphere), but once laws are made, administration is just a matter of execution. ${ }^{20}$ Thus administration is a domain of instrumental-analytic rather than communicative rationality. But let me suggest first, that the principles of communicative rationality also give us the conditions for effectiveness in the resolution of complex social problems (including environmental ones), and second, that intimations of these principles can already be found in environmental politics.

To begin with my first contention (and here I summarize a more intricate argument ${ }^{21}$ ), communicative rationality is conducive to social problem solving inasmuch as it enables the individuals concerned with different facets of a complex problem to pool their understandings and harmonize their actions in the light of reciprocal understanding of the various normative issues at stake. This process proceeds in nonhierarchical fashion, and so no cognitive burden is imposed on any decision center. The interaction between different facets of a problem that constitute complexity is matched by communicative interaction among the individuals who care about each facet. And of course, the conditions of these communicative interactions are crucial if they are to ameliorate rather than exacerbate complexity, which is why they must be regulated by the canons of communicative rationality. Ideally, the product would then be agreement on actions. Agreement need not take the form of consensus on the reasons for actions, though understanding of the reasons held by other participants is important. People

\footnotetext{
${ }^{18}$ Lindblom, Politics and Markets, pp. 170-188.

${ }^{19}$ See, for example, Jürgen Habermas, The Theory of Communicative Action, Vol. 1, Reason and the Rationalization of Society (Boston: Beacon Press, 1984).

${ }^{20}$ Habermas, Between Facts and Norms.

${ }^{21}$ For greater detail, see John S. Dryzek, Discursive Democracy: Politics, Policy, and Political Science (New York: Cambridge University Press, 1990), chs. 2 and 3.
} 
can often agree on what should be done without agreeing on an underlying normative framework. ${ }^{22}$

If my argument here holds, then one might anticipate institutional intimations of principles of free discourse - discursive designs - in the vicinity of complex social problems. Three such manifestations are worth noting in the environmental arena. In moving from the first to the third one finds increasingly less in the way of communicative purity, but more in the way of a problem-solving orientation.

The first category is celebrated by critical theorists and other radical philosophers: new social movements (usually defined in terms of their egalitarian style, lack of ambition to share in governmental authority, concern with identity issues, and lack of connection to the working class). These movements include feminists, peace groups, radical environmentalists, and anti-nuclear activists. All are committed to relatively free and open interaction in their internal workings, and sometimes in the larger political relationships which they engage. One might argue that this relative communicative purity is purchased at the expense of effectiveness. However, social movements take effect in the realm of culture, not just public policy. Consider, for example, the effects of both feminism and environmentalism over the past 35 years. Moreover, social movements can influence the state from a distance. German governments in the 1980s cancelled nuclear power projects and adopted increasingly progressive environmental policies while anti-nuclear forces were social movements denied access to policy making.

A more explicit problem orientation may be found in the second and smallest but (arguably) most significant of my three categories, discursively designed public inquiries. This category is exemplified by the efforts in both Canada and the U.S. of Thomas Berger, who has conducted a number of public inquiries on policy issues. Two of these have some connection with environmental issues: his inquiry into proposals to construct pipelines to bring oil and gas from the Canadian Arctic to southern markets, ${ }^{23}$ and his investigation of the condition of Alaska's Native peoples in the light of the 1971 Alaska Native Claims Settlement Act. ${ }^{24}$ These inquiries could be loosely styled as social and environmental impact assessment, inasmuch as they involve scrutiny of the effects of past actions and contemplation of the consequences of alternative development strategies for a region and a people. In both these cases Berger created a forum in which concerned and affected individuals could state, create, and develop their positions (especially through their participation in community hearings). Both consisted of prolonged interaction between Berger himself, relevant experts (at least in the pipelines case) and community members. Berger's reports contained recommendations for policy actions built upon these interactions. In the pipelines case, he recommended that no pipelines be constructed before the settlement of Native lands claims and the strengthening of the Northern renewable resource economy. In the Alaska case, he suggested dismantling the regional corporations established by the 1971 Act and the transfer of their assets to revitalized tribal governments, which would also exercise political control in Native Alaska. But in both cases he was summarizing a consensus reached through discourse among participants who attained a degree of communicative competence made possible by the kind of forum Berger established. $^{25}$

\footnotetext{
${ }^{22}$ See Alasdair Macintyre, "Does Applied Ethics Rest on a Mistake?", The Monist, 67 (1984), pp. 498-513.

${ }^{23}$ Thomas R. Berger, Northern Frontier, Northern Homeland: The Report of the MacKenzie Valley Pipeline Inquiry (Toronto: James Lorimer, 1977).

${ }^{24}$ Thomas R. Berger, Village Journey: The Report of the Alaska Native Review Commission (New York: Hill and Wang, 1985).

${ }^{25}$ For further approval of Berger's efforts on this score, see John Dryzek, "Policy Analysis as a Hermeneutic Activity," Policy Sciences 14 (1982), pp. 324-325; Douglas Torgerson, "Between Knowledge and Politics: Three Faces of Policy Analysis," Policy Sciences 19 (1986), pp. 46-51.
} 
My third category covers discursive exercises more closely tied to the state than new social movements or discursively designed public inquiries. (Berger's pipelines inquiry was commissioned by the Canadian government, but the way he conducted it surprised and dismayed his sponsors.) This category consists of procedures such as environmental mediation, regulatory negotiation, and alternative dispute resolution. These procedures have in common the idea that parties to a dispute can reason through their differences in pursuit of an action-oriented consensus under the auspices of a neutral third party. They are often proposed and undertaken as alternatives to more established forms of conflict resolution, such as litigation or even violence. In the case of environmental mediation, participants might include environmentalists, developers, polluters, community groups, and government officials. Many of the cases of environmental mediation carried out in the 25 years since the technique was introduced have concerned domestic U.S. disputes. ${ }^{26}$ Conflicts over local air pollution, mining, water supply system construction, highway siting, hazardous waste treatment and disposal, and land use have been mediated. In most cases a determinate outcome has been reached and eventually-though this is not guaranteed-embodied in public policy. The rise of mediation parallels and reflects an explosion of interest in informal dispute resolution in a variety of domains, international as well as domestic.

The kinds of exercises discussed in the previous paragraph involve stakeholders and partisans, and as such are prone to the continued strategic pursuit of self-interest. An alternative kind of design involves deliberation by randomly selected citizens with no prior partisanship (except by chance). In the 1990s, this principle informed citizen's juries (which began in Minnesota but have flourished in The United Kingdom), planning cells (in Germany), consensus conferences (invented in Denmark), and deliberative opinion polls (invented by James Fishkin in the United States and carried out in several countries). Representatives of interest groups may appear as witnesses, but are banished from actual deliberations. Such designs are intended to ascertain informed and considered public opinion. Normally they have an advisory rather than decision making role. However, their recommendations can sometimes be adopted in public policy (for example, a deliberative poll recommending greater stress on conservation helped to change electrical supply policy in Texas, and a citizen's jury has been decisive on at least one occasion in health policy in the United Kingdom).

\section{Discursive Designs in Context}

The most glaring shortcomings of the agenda for institutional reconstruction intimated in the preceding section is its inattention to the more or less automatic constraints upon collective decisions discussed earlier under the heading of context. In other words, to the extent they become involved in actual policy-making, discursive designs might fall victim to exactly the same kinds of constraints and imperatives as the administrative state.

The extensive critique of environmental mediation developed by Douglas Amy merits attention here. ${ }^{27}$ Amy argues that the fate and function of mediation is to co-opt potential troublemakers by extending to them the illusion of participation. Thus placated with symbolic rewards, environmentalists and others will acquiesce in "responsible" development or pollution, and capital will get its way no less than under more conventional political arrangements. Environmentalists and community activists will be seduced into becoming mere agents of the state and corporations, perhaps even of the Weberian process of instrumental rationalization. More insidiously, the very fact of sitting down on equal and reasonable terms with capitalists implies devaluation of moral concerns (for example, on

\footnotetext{
${ }^{26}$ For an early survey, see Gail Bingham, Resolving Environmental Disputes: A Decade of Experience (Washington, DC: The Conservation Foundation, 1986).

${ }^{27}$ Douglas Amy, The Politics of Environmental Mediation (New York: Columbia University Press, 1987).
} 
behalf of ecological integrity as a basic value) to the status of mere particular interests, fit for tradeoff against the profits of polluters and developers. At best, one can expect little more than the conspiratorial externalization of the costs of an agreement, which may benefit the parties at the table, but impose high costs on others (for example, consumers, or distant ecosystems). The coalition between Western environmentalists and Eastern coal producers mentioned earlier is indicative of this last possibility (though it should be stressed that this coalition had nothing to do with mediation or any similar procedure).

At present, environmental mediation and regulatory negotiation exist on the margins of environmental policy-making. If they were to become more central, then additional hazards in the form of the automatic constraint exercised by the market would loom larger. Policy-making discursive designs could not afford to upset market confidence any more than the administrative state could. How, then, may discursive designs be rescued from the state, capital, and market?

The critics of environmental mediation and alternative dispute resolution more generally are no help here, for all they ever recommend is a return to administration, litigation, or legislation. ${ }^{28}$ In other words, they offer only a dubious conservatism in the form of a return to a discredited, costly, arbitrary, and ineffective status quo. If industry is advantaged in mediation, then it is no less advantaged in the courts. ${ }^{29}$ Is there any alternative to this reactionary counsel?

The answer, it seems to me, is that discursive designs should seek a degree of distance from the state - and its economic imperatives. Such distance may of course be found in complete withdrawal from practical, problem-solving concerns, and sometimes new social movements adopt such a stance. ${ }^{30}$ But there is an alternative to such withdrawal. Discursive designs could be located within and help constitute an autonomous public sphere, separate from but confronting and pressuring the state. ${ }^{31}$ A public space of this sort is created whenever individuals congregate to scrutinize their relationships with one another and with the wider relations of power in which they are located. The subject of the public sphere is, as the name implies, public affairs. Perhaps the best historical example of a public sphere occurs in connection with the early bourgeois challenge to the feudal state, which disintegrated as the bourgeoisie itself sought and gained state power. ${ }^{32}$ Later, socialist parties and unions based in the working class confronted the state from which they were at first excluded. The working class public sphere diminished (but did not completely vanish) with the inclusion of its leadership in the emerging welfare state.

Today, an autonomous public sphere faces the task of discursively constructing challenges to the state. What, then, are the prospects for the development of such a public sphere free from domination by the agendas of corporations and/or the state? There are many obstacles, not least the ease with which some environmental leaders now access the state. Moderate environmentalists prize this access and influence over, but also complicity in, the process and content of public policy. More radical environmentalists such as Earth First!,

\footnotetext{
${ }^{28}$ See, e.g., David Schoenbrod, "Limits and Dangers of Environmental Mediation: A Review Essay," New York University Law Review 58 (1983).

${ }^{29}$ See Samuel P. Hays, Beauty, Health, and Permanence: Environmental Politics in the United States, 19551985 (New York: Cambridge University Press, 1987), p. 483.

${ }^{30}$ Such withdrawal is advocated for somewhat different reasons by Hannah Arendt, who believes authentic discursive politics can be found only in domains divorced from social problem solving. See Hannah Arendt, The Human Condition (Chicago: University of Chicago Press, 1958).

${ }^{31}$ See Torgerson, The Promise of Green Politics.

${ }^{32}$ See Jürgen Habermas, The Structural Transformation of the Public Sphere: A Inquiry into a Category of Bourgeois Society (Cambridge, MA: The M.I.T. Press, 1989 [1962]).
} 
Greenpeace, and anti-globalization protestors often reject both conventional strategic politics and the more discursive possibilities intimated here in favor of guerilla theatre. ${ }^{33}$

Some cause of optimism may be found in the efforts of Thomas Berger alluded to earlier. His Alaskan inquiry in particular constitutes an exemplary instance of the creation and sustenance of a public sphere in and through which a coherent challenge to the state is constructed, and a community is reconstituted. This inquiry was concerned with public affairs in two senses. First, its target was public policy (especially that of the U.S. federal government). Second, and perhaps more significantly, its subject was the self-determination of the collective future of a particular public-Alaskan Natives. The inquiry excluded government officials (except from local governments, which the inquiry was not challenging). It was constituted under the auspices of the Inuit Circumpolar Conference, a transnational organization of Inuit from Alaska, Canada, and Greenland, and financed by churches, foundations, local government, and Native Regional Corporations. The result was a forum in which ordinary Natives could testify, and to this end hearings were held in cities, villages, and fish camps throughout Alaska, at which 1450 individuals spoke. These individuals presented viewpoints, debated them, and argued with one another and with Berger, all in a context rendered meaningful by the existence and prior deliberations of the inquiry. Thus the commission did not just collect and collate individuals' positions; it also constructed a community position on land, economy, and governance, transforming sporadic protests by individuals and groups into a coherent challenge on behalf of a community and its way of life.

The establishment of a public sphere of this sort does not, of course, bring with it the abolition or even attenuation of the administrative state. However, this establishment does mean that the pressures upon the state from its capitalist and/or market context would be counterbalanced by the challenge from the public sphere. A cynical observer might claim that, no less than before, the interests of capital and market would always prevail in this unequal struggled. If so, then the public sphere would prove but a minor irritant, irrelevant in the larger political-economic structure. But other outcomes are conceivable. Berger's pipelines inquiry represents a challenge from the public sphere which eventually contributed to a state decision to overrule the interests of corporations; though the relative importance of this contribution compared to other influences on the decision (for example, a competing corporate proposal) remains unclear. And the public sphere created by new social movements

\footnotetext{
${ }^{33}$ A specific problem which arises in applying the idea of a public sphere to ecological matters should be mentioned. The concept of a public sphere - and its communicative rationality — are rooted in a philosophical tradition which claims there should be a radical discontinuity between human dealings with one another and human dealings with nature. This tradition encompasses Aristotle, latter-day Aristotelians such as Hannah Arendt, and the Frankfurt School of critical theory. Its members argue that collective human life should be so structured as to prevent it becoming like human interaction with the natural world, which can only be instrumental and manipulative. Today, this judgment is based on a fear that the scientific and technical attitudes which have proven effective in controlling nature are increasingly being turned to the control of people. An ecological critique of this tradition would argue two points. First, these scientific and technical attitudes are not as fruitful as they might seem, as contemporary environmental crises demonstrate. Second, there is a sense in which the natural world contains not just brute matter for human manipulation, but also agency. Recognition of this agency undermines the legitimacy of an instrumental, manipulative attitude to the natural world, just as a recognition of human agency undermines the legitimacy of social control. Acceptance of agency in nature does not imply a regressive commitment to nature's reenchantment. It finds echoes in the works of some contemporary natural scientists; see, e.g., James Lovelock, Gaia: A New Look at Life on Earth (New York: Oxford University Press, 1979), and Evelyn Fox Keller, A Feeling for the Organism: The Life and Work of Barbara McLintock (San Francisco: W. H. Freeman, 1983). Thus there may be a sense in which natural entities can indeed participate in communicative practice. For a preliminary discussion of the implications of this recognition, see John S. Dryzek, "Green Reason: Communicative Ethics for the Biosphere," Environmental Ethics, 12 (1990), pp. 195-210.
} 
does occasionally exert some influence (as my previous example of Germany in the 1980s makes clear).

Despite the possibilities associated with the idea of a public sphere, one should not underestimate the obduracy of the market, capitalism, and the administrative state itself. Moreover, it is hard to undermine these three obstacles to freely discursive public life simultaneously. Eliminating the free market is conceivable, and indeed done quite often - but all such elimination usually produces is either monopoly capitalism and corporatism, with a concomitant enhanced capacity to exert direct pressure on the state, or an old-fashioned command economy which exacerbates the epistemological problems of administration discussed earlier. Abolishing capitalism, now hardly conceivable, might give us market socialism of some sort, which is as capable as a capitalist market of inflicting automatic punishment on government actions that threaten profitability, or, again, an economic system administered by state bureaucrats. Limiting the administrative state might produce only more of the market or monopoly capitalism (as in Chinese and Russian economic reforms).

As things stand, then, discursive designs are not in and of themselves blueprints for an alternative political-economic system. What they do offer is a challenge to dominant institutional forms, which might contribute to a reconsideration of the way we order collective life. But in maintaining this challenge, proponents of and participants in discursive designs should be careful to avoid complicity in the complex status quo to which discursive designs offer the hope of an alternative.

\section{Recent Transformations}

Any more extensive and consequential role for environmental discursive designs in transforming the character of the administrative state could only be achieved if state imperatives were less ineluctably stacked against both environmental values and the indeterminacy that democratic control connotes. There are in fact two ways in which state transformation may be occurring in just these terms, though they turn out not to be available to all states equally.

The first transformation comes with the increasing salience of issues relating to environmental risk. It is the thesis of Ulrich Beck that industrial society is undergoing transformation into risk society, whose defining feature is that the public no longer accepts risks as inevitably side effects of 'progress', but instead regards them as undermining the basic ideas of technological progress and economic growth. ${ }^{34}$ The resultant 'reflexive modernity' therefore involves society's confrontation with its own economic foundations, opening up new possibilities for what Beck calls 'subpolitics', which would cover a lot of the institutional innovations that I have styled discursive designs. If Beck is right, then risk issues present a legitimation crisis of the state - and given that legitimation is a core state imperative, it enables environmentalists to attach their defining interests to a core state imperative more securely than before. However, it is a big "if". Beck can support his case with a few examples from Germany in particular; but even there, politics is still mostly dominated by the old distributional conflicts and economic management issues of industrial society.

The second transformation is also most well-developed in Northern Europe, in the form of an increasingly consequential discourse of ecological modernization. The basic idea of ecological modernization is that economic and environmental values can be mutually reinforcing. The reason is that pollution reduction equals efficiency in material usage and so production more generally. A clean environment means happy and healthy workers and high-quality inputs into economic processes (for example, clean water). There is money to be made in abatement technology. ${ }^{35}$ To the extent this

\footnotetext{
${ }^{34}$ Ulrich Beck, Risk Society: Towards a New Modernity. London: Sage.

${ }^{35}$ There is now an extensive literature on ecological modernization. See, for example, Peter Christoff, "Ecological Modernisation, Ecological Modernities," Environmental Politics, 5 (1996), pp. 476-500; and the special issue of Environmental Politics, 9 (1), Spring 2000.
} 
scenario holds, then the conflict between the state's economic imperative and environmental values is weakened, and indeed environmentalists can try to attach their interests to the economic imperative.

These two transformations do not, however, dispense with the need for more radical action in and through the green public sphere. Ecological modernization as a merely technocratic project does not need discursive democratization, and the technical changes to production processes that it entails do not constitute substantial transition to a greener political economy. For example, producing ever more fuel efficient and less polluting cars is no use if the benefits are outpaced by growing numbers of cars and increases in miles per car per year traveled. ${ }^{36} \mathrm{~A}$ stronger version of ecological modernization would involve putting more basic questions about the structure of the political economy on the table ${ }^{37}$ - and the table itself would have to be a more discursively democratic one in order for these questions to be raised. Turning to risk-induced legitimation crisis, that crisis only takes effect because of the presence of powerful oppositional forces in the green public sphere. The discursive subpolitics of which Beck speaks somehow has to involve these forces, without blunting their critical edge. In sketching discursive designs at various degrees of distance from the state, I believe the requirements of such a vital, critical, and yet productive (in public policy terms) subpolitics can be met. This kind of subpolitics would be exactly what is required to push ecological modernization in a stronger direction.

Both ecological modernization and the risk society scenario have in recent years played themselves out much more strongly in Northern Europe - specifically, Scandinavia, the Netherlands, and Germany - than elsewhere. This explains why these countries are now environmental policy leaders, and why the United States, once is leader, is now a laggard. ${ }^{38}$ Ecological modernization is hardly on the horizon in the United States, still stuck in an old-fashioned standoff between supporters and opponents of the environmental policy regime established around 1970, and barely updated since. The existence of the environmental justice movement in the United States shows that issues of environmental risk and an associated discursive subpolitics do exist there. ${ }^{39}$ But absent any ecological modernization discourse, the conflict with the state's core economic imperative is just too intense, and economics normally prevails to frustrate both further discursive democratization and any more serious pursuit of ecological values.

Still, the conclusion is more positive than it was a dozen years ago. The progress may be glacial, but at least now there are glimmers of what a green and discursively democratic - or, rather, greener and more discursively democratic state - might look like. But such a state cannot be envisaged without a green and discursively democratic public sphere at a critical distance.

\footnotetext{
${ }^{36}$ George A. Gonzalez, "Democratic Ethics and Ecological Modernization: The Formulation of California's Automobile Emission Standards," Public Integrity, 3 (2001), pp. 325-44.

${ }^{37}$ Christoff, "Ecological Modernisation."

${ }^{38}$ John S. Dryzek, David Downes, Christian Hunold, David Schlosberg, with Hans-Kristian Hernes, Green States and Social Movements: Environmentalism in the United States, United Kingdom, Germany, and Norway (Oxford: Oxford University Press, 2003).

${ }^{39}$ David Schlosberg, Environmental Justice and the New Pluralism: The Challenge of Difference for Environmentalism (Oxford: Oxford University Press, 1999).
} 